\title{
特集 ポスト東日本大震災の防災・減災まちづくり【論説】
}

\section{防災法制度の構造的課題と展望}

The structural problem and future prospects concerning the legal system of disaster prevention

\section{I 対症療法的改正を続けてきた防災法制 と東日本大震災を契機に行われた改正}

我が国の防災法制は, 大規模な災害が起こる度 に, 問題となった事象を解決するため, 対症療法 的な改正を繰り返してきており, その基本構造に 手が入れられることが殆どないまま, 東日本大震 災を迎えた1。未曾有の都市災害と言われた阪神 大震災の時でさえ，多くの法改正が行われたにも かかわらず，それらの殆どは防災の基本法である 災害対策基本法の外側で行われ，基本構造には殆 ど触れられないままであった。

東日本大震災については, (1)津波による被害が 大きかったこと, (2)被害が大規模, 広域, 激甚な ものであったこと, (3)原子力災害が生じたこと, が大きな特色として挙げられるが, これらについ ては，(1)に対して「津波防災地域づくりに関する 法律」の制定等が行われ, (2)については, 市町村 主体の災害対策中心に構成されていた災害対策基 本法を二度にわたって改正して ${ }^{2}$, 国等が前面に 出て応急対策を実施する仕組みを中心とした規定 の整備が行われるとともに, 復興を進めるための 「東日本大震災復興基本法」や「東日本大震災復 興特別区域法」の制定等が行われた。また，(3)に ついては, 原子力規制委員会設置法, 原子炉等規
制法の改正等が行われたが，これらを含め，法的 対応の多くは対症療法的色彩が強く認められる。

しかし, 東日本大震災を受けて行われた平成 25 年の災害対策基本法改正には, これまで行われて こなかった防災法体系の構造に変化をもたらす内 容が含まれていることが注目される。この改正で, 基本法の中に「災害対策の基本理念」規定が新設 されたが, 特にその中で「災害のリスクの程度を 踏まえた対策の必要性」という考え方が明確にさ れたこと等は，今後の贸害対策の展開において極 めて重要な意味を持つと考えられる。

周知の通り, 東日本大震災では, 1000年に一度 という滅多に生じない津波により甚大な被害が生 じたのであるが，それまでの防災法制は，一言で 言えば，我が国社会において頻繁に生じる中規模 一過性の災害を念頭に置いたものとなっており， 滅多に生じることのない大規模・長期災害に対応 する仕組みは殆ど組み込まれていなかったと言え る。その背景には, そもそも滅多に生じないよう な大規模災害に常時対応できるような防災体制を 整備し, これを維持するのは, 無駄が多く, 現実 的でないという考えがあったからである3。

このような中で，災害対策の理念として「災害 のリスクの程度に対応する防災措置」という考え 方が改めて明確にされたことは, 今後防災法構造

\footnotetext{
生田 長人*（いくた おさと）東北大学名誉教授

1 その理由については拙稿「災害対策法制の抱える主要課題とその検討の視点」自治研究第89巻第 1 号 37 頁

2 平成 24 年 (法律第41号) と平成25年（法律第54号）の 2 度改正が行われた。

3 例えば, 1000年に一度の災害を前提として, ハードな防災施設を整備したり, 災害応急対策を担う防災機関の人員体制 を常に維持すること等は現実に想定し難い。
} 
にどういう影響を及ぼすのか。

その最も大きな影響の一つは, 頻発する中規模 一過性の災害を念頭にハードな防災施設の整備を 中心に対応してきたこれまでの防災対策では，大 規模災害には対応できないということを踏まえ， そのような大規模災害の場合でも国民の生命だけ は守るという仕組み, つまり万一に備えた避難の 仕組みや街づくりを進めることを重要な防災施策 として位置づけ，重点が置かれることになると考 えられる。既に、前述した「津波防災地域づくり 法」では，ハード・ソフトの防災措置を組み合わ せ，大規模津波が生じた場合でも住民の生命は守 るといういわゆる多重防御の仕組みが組み込まれ ているが，今後は，津波に限らず，およそ全ての 災害に対してもこのような考え方に立った対応を 行う必要があることが明示されたのである。

また，もう一つの大きな点として，大規模災害 の対応では, 防災関係機関による公助中心の災害 対策に加えて, 自助・共助による災害対策の展開 が不可欠となるということが挙げられよう。先の 災害対策基本法改正では，大規模災害時に国等が 前面に出る形の仕組みを整備したことを述べたが, 公的機関による応急対策をどれだけ充実したとし ても，大規模災害時の初期応急対策に限界がある ことは, 既に阪神淡路大震災でも明らかになって いる。現実には, 大規模災害の場合ほど, 公助で カバーできる範囲は限定され, 被災者は自分達の 身を自分達の手で守らざるを得ない状況に直面せ ざるを得ない。このようなことを踏まえて，平成 25年改正では，プロ集団としての防災関係機関だ けではなく，住民等も含めた大規模災害対応のた めの具体的な手段として「地区防災計画」制度が 整備されている。

\section{II 残されている課題と展望…構造改善が 必要な法制度部分}

I で述べたように，平成25年の災害対策基本法 改正によって掲げられた災害対策の基本理念は防 災法制の基本構造の変革を迫るものであるが，今 のところ法的対応がなされたのは，一部の大規模 災害対応に係る部分に過ぎず，今後なお，防災法 制は多くの構造改善を要すると考えられる。以下 では，災害予防，災害応急対策，災害復旧・災害 復興の局面に分けて，その主な点を展望する。

\section{1 災害予防の分野}

「災害リスクの程度を踏まえた防災対策」の展 開により，大きな改善が避けられないのが災害予 防の分野である。なかでも, 発生頻度の高い中規 模一過性の災害を念頭に置いて構成されている防 災計画体系は，その根底からの見直しが必要とな ろう。

現行の防災計画では, 災害予防の計画と災害応 急対策の計画という元々性格の異なる二つの内容 が定められる。このうち, 災害予防計画の部分で は, 災害の夕イプごとに, 被害の防止軽減を図る ため平常時に講じておく内容を定めなければなら ないが, これまでの中規模一過型災害を念頭に置 いたワンパターンの内容では十分と言えなくなり， 災害の発生リスクを念頭に置いて，どの程度の規 模の災害に対して，どのような予防手段を組み合 わせて対応するか4を定めることが要請されるこ とになるので，その内容の抜本的見直し検討が避 けられないと思われる。

この見直し検討については, 現実には厳しい 様々なハードルが存在する。例えば災害危険度が 高い特定の区域における災害予防手段としては 「災害防御施設の整備」や「災害予防のための土 地利用規制の実施」などの施策が考えられるが，

\footnotetext{
4 例えば, 発生頻度が高いものに対しては, 災害防御施設の計画的整備や土地利用規制等で対応し, 発生頻度の低いもの については，万一の場合に備えて的確な避難が実現できるような仕組みを定めるといった対応である。
} 
そのいずれを選択すべきかという点を取り上げて も，現行制度に明確な基準となる考え方があるわ けではない。我が国では，これまで災害防御施設 の整備中心の災害予防が行われてきたが, 膨大な 費用と長い整備期間を要することから, 今後対応 できる範囲が極めて限定されているのが現実であ る。かといって土地所有者に補償措置も講ぜず負 担を負わせる土地利用規制が広汎に適用できるわ けでもない。このような例を挙げるまでもなく， 災害リスクを前提として実効ある災害予防策を進 めていくためには, 多くの乗り越えなければなら ないハードルがあり, 様々な角度から現実的な検 討を進めることが必要となるであろう5。

第二に，災害応急対策計画の部分では，現実に 災害が生じた場合等に実施しなければならない措 置を事前に定めておかなければならないが，この 部分は災害時に実施しなければならない措置を定 める以上, 実効性の高いアクションプランでなけ れば意味がない。しかし, 現在の防災計画では, 対応しなければならない災害の規模等に触れるこ となく，災害が発生したときには「かくかくしか じかのことを行う」と書かれている例が多く見受 けられる。こうした書き方は, どのような規模の 災害に際しても対応できるかのような䛊解を生じ させるが, 現実には, 大規模災害の場合, 書かれ てある内容を実施することは難しく, 多くの被災 者は自らの身を自分達の力で守らなければならな い状態に追い込まれる。

滅多に生じることのない発生頻度の低い災害に も常時対応できるように防災側の体勢を執ること が現実的ではないとすれば, 現行の防災体勢でど こまでの規模の災害にどれだけ対応できるのかを 計画中で明示しておく必要があり, 対応が難しい 場合に, 被災者がどの様に対処すべきかを明示し ておくのが応急対策にかかる防災計画のあるべき 姿ではないか。発生頻度の低い大規模災害の場合
の応急対策における「公助の現実」と「自助・共 助」の対応を可能にする事前措置を定めておくこ とが不可欠であろう。

\section{2 災害応急対策}

現実に災害が生じた場合或いはそのおそれが切 迫している場合に, 防災機関が中心となって実施 しなければならない措置を規定するのが「災害応 急対策法制」の分野である。

この分野については, 東日本大震災を契機に行 われた法制度整備で大規模災害に対応するための 改善が図られたが, その内容は, 市町村が対応で きない場合に国等が応急対策に乗り出すいわば垂 直的支援体制を強化·整備したものであった。こ のこと自体が必要なことであるのは間違いないが, 現実には垂直的支援ではカバーできない部分も多 く, 今後, 改善の対象とならなかった水平的支援 (市町村や都道府県相互間支援) 体制の充実·強化 や民間機関や住民の総力を挙げた協力体制の確立 が急がれる。

この分野で残された構造問題としては, 上記の ような大規模災害対応と併せて,「長期継続型災 害」に見られるような「長期にわたる避難生活を 余儀なくされる場合の応急対策」の問題がある。

現在, 災害によって避難を余儀なくされた被災 者に対しては, 災害救助法に基づき, 最低限の生 活を維持するために必要なものが無償で提供され る「災害救助」という仕組みが設けられているが, 災害が「一過型」でなく，「長期継続型（例えば 火山噴火や原子力災害)」である場合にこの仕組 みがこのままで良いのかという問題である。「中 規模一過性」の災害を念頭に置いている現行の防 災法制では, 被災した者に対する応急救助もまた 短期間の避難を想定しているため, 避難者が受け る救助は, 一次的避難所である体育館等で雨露を 凌ぎ，おにぎりと水と毛布の提供といった最低限

\footnotetext{
5 参考として, 拙稿「土地利用と防災」(論究ジュリスト15号 (2015年) 45頁以下)

${ }^{6}$ 拙稿「防災計画のあり方に関する考察」(防災の法制度に関する立法政策的研究…その 1 」(国土交通政策研究所) 29 頁以 下)
} 
の内容となっていることは周知の通りである。こ のため, 避難が長期間に及ぶと被災者の多くは耐 その限界に置かれ，悲惨な状況に陥ることが多い。 これと同様の問題は，災害が大規模激甚であるた めに，避難が長期間に及ぶ場合にも生じる。

中規模一過性災害を前提とした「短期の災害応 急対策」という性格を有している現行の「災害救 助」には, どうしても，(1)救助水準の低さと(2)現 物給付方針をとっているが故に避けられない被桨 者ニーズの無視，という二つの大きな問題が付き まとう。

(1)については, 災害救助が, 個人の力ではどう することもできない災害直後の状況下における 「必要最小限の緊急的支援」として位置づけられ ていることに起因している7のであるが，プライ バシーがなく，寝る場と最低水準の食事が提供さ れるだけの避難所生活は，短期間であれば許容さ れるとしても，長期にわたる場合，憲法上の最低 生活水準に抵触するのではないか。

また，(2)の「現物給付」方針 ともかく, 時間が経過した時点では被災者の多様 なニーズに対応できず, 避難生活が長引くと, 非 効率で無駄な現物給付は避難者を苦しめる現実が ある。住む場所を失って避難所以外に行き場所の ない被災者が切望するのは, プライバシーを確保 できる住まい，ニーズを満たすことのできる衣食 であるが，被災者に対して提供される「救助」は， 時間の経過に関わりなく, 被災者の置かれた多様 な状況を無視した最低限の現物給付が基本である。

例えば, 住まい一つを見ても, 避難所からの脱 出を願う被災者に対し, 救助法に基づいて提供さ れるのは基本的に現物給付としての「応急仮設住 宅」である。仮設住宅は用地の確保に時間がかか
り, 避難所からの脱出が長引く最大の理由となっ ているとともに，戸当たり600万円を超える費用 がかかる割には住まいとしての水準は低く，大規 模災害の場合には, 法定の存続期間の 2 年を遙か に超える長期間の居住を被災者に強いている。災 害からかなりの期間が経った時点でなおこれを応 急救助と位置づけ, 現物給付に拘る理由は見当た らず, バウチャー制度9等を含め被災者ニーズに 対応できる復旧段階としての多様な住まいの確保 策を検討すべきである。

\section{3 災害復旧と災害復興}

東日本大震災を契機として，災害復旧·災害復 興の分野においても多くの法令の整備が行われた が，その殆どは現実の被害からの復旧·復興を促 進する対症療法的なものであり，防災法制の基本 構造に係る改善は行われなかった。災害対策基本 法では，依然として，計画的な復旧や復興に欠か せない災害復旧計画と災害復興計画制度は未整備 のままである。なぜ構造的な改善が行われなかっ たのかという背景には，災害復旧や災害復興は基 本的に被災した側の責任で行うべきものという考 え方が我が国に存在するからだと考えられる。こ の考え方が適切なものであるかについては，極め て重要な議論の対象であると考えるが, 本稿では, この点に触れるだけの紙面の余裕がないので10, とりあえず，法定化された復旧計画·復興計画制 度が存在しないことによる主な問題点を挙げてお くに留める。

\section{i 災害復旧と災害復興の基本的な性格の 差について}

法制上「災害復旧」を定義した規定はなく，そ

\footnotetext{
7 災害救助法の救助は，災害時における憲法第25条の国民の基本的生存の保障を具現化したもので，応急的，一時的救助 と位置づけられていることによる。

8 災害直後においては，金銭を給付しても必要な物資の購入が困難であるというのが現物給付の主たる理由とされている。

9 このケースでは, 国等が被災者に対し，家賃に充てることができる一定額の引換券を交付し，被災者がニーズに合った 住まいの家貨に使えることとする仕組みを指している。

10 この点についての検討については，前掲注 6 の「国等の防災責任に関する考察」を参照。
} 
の範囲は不明確であるが，法律上の使用例を見る 限り，災害復旧は「被災した施設や建物や設備を 被災前の状態（原形）に戻す（機能を回復する場 合も含む)」という意味で使われており，かなり 狭い概念である。現行法上災害復旧の分野で助成 制度の対象とされているのは, 社会的に公共性が 高く, 迅速な復旧が必要とされるものに限定され ている(公共公益施設の災害復旧制度等)。災害 によって打撃を受ける範囲は広いが, 被災者の生 活再建, 被災地の地域社会の再建, 被災地経済の 再建などについては, 法律上の「災害復旧」概念 に該当するかどうかは不明確である。これらに対 して現在災害復旧の名の下で行われている支援策 には, 先に述べた災害応急対策の救助として行わ れているものが多い。

災害復興の分野においても, 災害復旧同様, 被 災した側の責任で行われるのが原則であり，国等 が特別に支援を行っているのは, 社会的, 経済的 に全国的な影響をもたらすおそれがある大規模災 害の場合に限られている11。しかし, 災害復興に 関する支援の必要性は, 災害の規模の大きさのみ で判断されるべきものではなく, 被災地が受けた 打撃の強さで判断すべきものと考えられ, 大規模 災害に限って復興支援が行われる現行制度は適切 さを欠いている。なお，「災害復興」という用語 についても法制上定義が扔かれていないが，これ までの法律上の使用例では,「単なる災害復旧に 留まらない...新たな地域社会の構築…を目指して 行われる」一連の諸活動を指す極めて広い概念の ようである ${ }^{12}$ 。

両者の決定的な違いは, 復旧の場合, その視点 が過去に向けられているのに対して, 復興の場合 は，未来に向けられているという点にあろう。
現行法上「災害復旧」として行われているもの の多くは, できる限り迅速に行う必要があるもの であるが，これに対して「災害復興」に当たるも のについては, 被災地の将来の姿に関して地域の 基本合意があることが不可欠であり，十分な時間 をかけた議論が必要と考えられるため, 災害復旧 と異なり, 被災後直ちに行うべきものとは言えな いところがある。

災害対策基本法は「災害復旧」と「災害復興」 の明確な規定を欠いているために, 被災後, 地方 公共団体が事実上作成する再建計画には，この性 格の異なる二つが混淆して定められることが多く， これが被災地の復興に大きな混乱をもたらしてい ることは残念である。

\section{ii 被災地に必要な整合性のとれた計画的 な復旧や復興が実施されないことについて}

災害復旧の計画制度が法定化されていないこと によるもう一つの問題は, 対象施設の復旧の必要 性や時期等に関する判断がそれぞれの施設の管理 者によってランダムに行われる点である。このた め, 被災地の意向が各施設の管理者の復旧方針に 反映されない場合, 早く復旧させなければならな いものが後回しにされたりして, 被災地全体とし て計画的で的確な復旧に支障が生じるおそれがあ る仕組みとなっている ${ }^{13}$ 。

また，災害復興の計画制度が法定化されていな いことにより，被災直後に十分な検討がなされな いまま復興事業が定められたり, 被災地の将来ビ ジョンに住民の意向が的確に反映しなかったりす るなど, 多くの問題が生じているのが実態ではな いか。

\footnotetext{
11 阪神淡路大震災や東日本大震災の場合，それぞれ特別法が作られ，復興に関する措置が定められる形となっていた。平 成25年に「大規模災害からの復興に関する法律」が制定され, 復興のための特別措置等を講じる仕組みが定められたが, その対象は著しく異常かつ激甚な非常災害で緊急災害対策本部の設置がされたものに限られている。

12 東日本大震災復興基本法第 2 条等

13 例えば交通インフラのようにネットワークとして機能するものについては, 支線的施設が先に復旧しても幹線的施設が 未復旧であれば全体として機能しないことが考えられる。
} 


\section{4 被災者の生活再建等}

防災法制全体を通してみると, 被災者が直面す る生活再建等に対する支援は極めて手薄であると いう感が否めない。被災者がその生活を立て直す に当たって直面する最も深刻な問題には，(1)住ま いの確保，(2)生活を支える収入の途絶或いは減少 による困窮等がある。

(1)については，住まいを失った被災者に対し， 当面の住まいとして応急仮設住宅の提供が行われ， 恒久的な住まいの確保支援としては, 自力で再建 等が可能な場合は必要な費用に関し低利融資, 自 力で住まいの確保が困難な者に対しては災害復興 公営住宅の提供が行われる他, 被災者生活再建支 援法の支援金の給付も行われ，(2)と比較すると支 援制度が整備されていると言えるが，応急仮設住 宅制度に問題が多いことは既に述べたとおりであ る。

(2)の点については，社会的に問題となった大災 害の場合を除いて，支援のための法制度が極めて そしいのが現状である。

被災に伴う失職, 生業手段の衰失等によって,
収入の道を絶たれた被災者は深刻な状況に陥り， あらたな生活再建に取り組む余裕すらない場合も 多い。前述した被災者生活再建支援法は，阪神淡 路大震災を契機に, 自力では生活再建が難しい被 災者に対する生活支援を目的に整備されたもので あったが，その後，支援金を住宅の再建に使用で きるようにすべきという全国知事会の意向を受け た改正により，生活に困窮する被災者に対する支 援法制という性格が薄れ，住まいを失った者であ れば金持ちでも受給できる仕組みに変り，住まい の衰失に対する一時的見舞金と化した。被災によ り困窮する事態に陥った場合の支援という性格が 失われたことは非常に遺憾である。

この制度は，災害により住まいを失った場合に しか適用されないが，被災により生活に困窮する に至った者は住宅に甚大な被害を受けた者とは限 らないことから，現在のこの制度の仕組みには基 本的な問題がある。被災者生活再建支援制度は, 被災者が置かれている困難度に応じ，生活再建に つなげるトータルな支援制度への再編が必要であ ると考える ${ }^{14}$ 。

\footnotetext{
14 被災により生活困窮状態に陥った場合，最終的には生活保護制度で対応すべきという考え方があるが，被災者が無資産 になることを適用要件としているため，災害から立ち上がろうとする意欲がある被災者の生活再建にはつながらない。 被災により, その生活が生活保護水準以下の状況に陥った被災者が, 被災地に生活の本拠を置いて生活の再建を目指す 場合には，その身の回りの生活資産を処分しないままでも，一定期間，前月収入と生活保護費との差を支給することを 内容とする災害時の特別の生活保護制度などを検討すべきであろう。
} 